\title{
Budd-Chiari Syndrome: Long term success via hepatic decompression using transjugular intrahepatic porto-systemic shunt
}

Alexandra Zahn ${ }^{1 *}$, Daniel Gotthardt ${ }^{1}$, Karl Heinz Weiss ${ }^{1}$, Götz Richter $^{2}$, Jan Schmidt ${ }^{3}$, Wolfgang Stremmel ${ }^{1}$, Peter Sauer ${ }^{1}$

\begin{abstract}
Background: Budd-Chiari syndrome (BCS) generally implies thrombosis of the hepatic veins and/or the intrahepatic or suprahepatic inferior vena cava. Treatment depends on the underlying cause, the anatomic location, the extent of the thrombotic process and the functional capacity of the liver. It can be divided into medical treatment including anticoagulation and thrombolysis, radiological procedures such as angioplasty and transjugular intrahepatic porto-systemic shunt (TIPS) and surgical interventions including orthotopic liver transplantation (OLT). Controlled trials or reports on larger cohorts are limited due to rare disease frequency. The aim of this study was to report our single centre long term results of patients with BCS receiving one of three treatment options i.e. medication only, TIPS or OLT on an individually based decision of our local expert group.
\end{abstract}

Methods: 20 patients with acute, subacute or chronic BCS were treated between 1988 and 2008. Clinical records were analysed with respect to underlying disease, therapeutic interventions, complications and overall outcome.

Results: 16 women and 4 men with a mean age of $34 \pm 12$ years (range: 14-60 years) at time of diagnosis were included. Myeloproliferative disorders or a plasmatic coagulopathy were identified as underlying disease in 13 patients, in the other patients the cause of BCS remained unclear. 12 patients presented with an acute BCS, 8 with a subacute or chronic disease. 13 patients underwent TIPS, 4 patients OLT as initial therapy, 2 patients required only symptomatic therapy, and one patient died from liver failure before any specific treatment could be initiated. Eleven of 13 TIPS patients required $2.5 \pm 2.4$ revisions (range: $0-8$ ). One patient died from his underlying hematologic disease. The residual 12 patients still have stable liver function not requiring OLT. All 4 patients who underwent OLT as initial treatment, required re-OLT due to thrombembolic complications of the graft. Survival in the TIPS group was $92.3 \%$ and in the OLT group 75\% during a median follow-up of 4 and 11.5 years, respectively.

Conclusion: Our results confirm the role of TIPS in the management of patients with acute, subacute and chronic BCS. The limited number of patients with OLT does not allow to draw a meaningful conclusion. However, the underlying disease may generate major complications, a reason why OLT should be limited to patients who cannot be managed by TIPS.

\section{Background}

Budd-Chiari syndrome (BCS) is a rare disorder defined as a hepatic venous outflow obstruction at any level between the hepatic veins and the right atrium [1] but generally implies thrombosis of the hepatic veins and/or the intrahepatic or suprahepatic inferior vena cava (IVC). Up to $50 \%$

\footnotetext{
* Correspondence: alexandra.zahn@med.uni-heidelberg.de 'Department of Gastroenterology, University Hospital Heidelberg, Im Neuenheimer Feld 410, 69120 Heidelberg, Germany
}

of all cases of BCS are due to chronic myeloproliferative disorders like polycythemia vera (PV) [2] or coagulopathies like factor $\mathrm{V}$ (Leiden) gene mutation [3-5]. The clinical presentation is highly variable but may be categorized as acute and perhaps fulminant hepatic failure, as subacute without evidence of cirrhosis or as chronic with evidence of portal hypertension and cirrhosis.

Treatment depends on the underlying cause, the anatomic location, the extent of the thrombotic process and 
the severity of liver disease. Treatment options can be divided into medical treatment including anticoagulation and thrombolysis [6-8], radiological procedures such as angioplasty [9] and transjugular intrahepatic porto-systemic shunt (TIPS) [10-14] and surgical procedures including porto-systemic shunting (PSS) [15-17] and orthotopic liver transplantation (OLT) $[18,19]$. Anticoagulation alone is unlikely to lead to sufficient recanalization of occluded vessels, or development of adequate collateral circulation. However, satisfactory long-term survival with only medical therapy has been reported $[6,20]$. Recent data failed to show a favorable impact of PSS on survival $[17,21]$, while TIPS has shown encouraging results [11-13,22-25].

This may give rise to redefine the role of OLT which may now be preserved for patients failing TIPS. The present treatment recommendations of BCS $[26,27]$ are not based on randomized studies but on a small number of retrospective studies $[8,25,27]$ and one prospective study [20].

The aim of this single centre retrospective study was to further enlarge the body of patients evaluated with the intention to allow steady optimization of present treatment strategies.

\section{Methods}

\section{Study design}

Patients admitted between 1988 and 2008 with a primary diagnosis of BCS were enrolled into this retrospective analysis. All available medical records especially laboratory data, radiological imaging and procedures, surgical interventions and discharge letters were reviewed. All data at the time of diagnosis and of new treatment were considered. Date of diagnosis was the date of the first investigation when the criteria for diagnosis were fulfilled. BCS was defined following the European network for vascular disorders of the liver (EnVie) [28] criteria and the last Baveno consensus based on imaging showing an obstructed venous outflow tract [26]. Diagnosis of BCS was made by either Doppler ultrasonography, magnetic resonance imaging or computerized tomography.

Disease severity was defined as acute, subacute or chronic. In contrast to the acute disease, the subacute and chronic forms were assumed to be present for several weeks to more than six months prior to clinical presentation [29].

Different from the last Baveno consensus [26] treatment was only partly applied in a stepwise manner. On the basis of radiological imaging and the severity of clinical presentation a decision by an experienced interdisciplinary team concerning adequate treatment was reached. This could either be a medical treatment or a prompt intervention. If patients did not improve on medical therapy TIPS insertion was performed.

Patients who underwent OLT as initial therapy were not candidates for TIPS. Two patients were transplanted before TIPS had been introduced as a treatment option of BCS, namely in 1988 and 1992. The other patients had cirrhosis with signs of chronic liver failure in terms of hepatic encephalopathy and high bilirubin levels so that liver transplantation was considered essential in these patients.

\section{Hematological evaluation of hypercoagulable state}

To identify a hypercoagulable state as the underlying etiology of BCS each patient received a comprehensive hematological evaluation. The latter was performed stepwise and included antiphospholipid antibodies, homocysteine levels, testing for factor $\mathrm{V}$ (Leiden) and prothrombin (20210) mutation, APC resistance, ATIII, protein $\mathrm{C}$ and $\mathrm{S}$ levels. Patients in whom a myeloproliferative disorder (MPD) like PV or essential thrombocytosis was suspected received a bone marrow biopsy. As our study begun in 1988, not all of our patients were screened for the JAK2V617F mutation.

\section{TIPS Technique and OLT}

All TIPS were created using standard techniques [30-32] by insertion of Palmaz stents (Johnson and Johnson Interventional Systems, Warren, New Jersey), Wallstents (Schneider, Minneapolis, Minnesota) or covered Viatorr stents (GORE, Flagstaff, AZ). When a hepatic vein remnant was not present the portal vein was punctured directly from the IVC [30]. After the TIPS procedure patients underwent anticoagulation according to the guidelines [26]. Patients underwent control angiography 3 months after TIPS and in addition if shunt dysfunction was suspected. An abdominal ultrasound was performed every 6 months. TIPS dysfunction was defined as an increase in portosystemic gradient above 10 to 12 $\mathrm{mmHg}$ and clinical signs of portal hypertension.

In our liver transplantation program the modified piggyback technique by Belghiti [33] has been used as a routine surgical procedure since 2001. Before 2001, the so-called piggyback technique had been applied [34,35].

\section{Statistical analysis}

Descriptive statistics were provided as mean \pm standard deviation (SD) and as range. The cumulative survival probability was estimated by the method described by Kaplan and Meier. All analyses were carried out in Microsoft Excel and SPSS.

The study protocol conformed to the ethical guidelines of the Helsinki Declaration, and was approved by the ethics committee of the University of Heidelberg. 


\section{Results}

\section{Patients characteristics}

20 patients, 4 male and 16 female, were included in our study. Patient age ranged from 14 to 60 with a mean age of $34 \pm 12$ years. Patients characteristics are given in table 1. Myeloproliferative disorders (especially PV) were the cause of BCS in 6 patients, 7 patients had plasmatic coagulation abnormalities, 1 patient took oestrogen medication as a possible underlying hypercoagulable condition and in 6 patients the aetiology of BCS remained unclear. As not all of our patients were screened for the JAK2V617F mutation latent MPD may have been missed in several patients. 12 patients presented with acute BCS, 8 with subacute or chronic disease. 8 patients presented with abdominal pain, 3 with new onset of ascites, 7 with abdominal pain plus new onset of ascites, 1 with gastrointestinal bleeding plus ascites and 1 with acute liver failure.

\section{Treatment and outcome}

13 patients underwent TIPS (10 women, 3 men) and 4 underwent OLT (3 women, 1 man) as initial therapy. One of the remaining 3 patients died of fulminant liver failure rapidly after the initial diagnosis, the other patients have not had an intervention, yet as their status was stable under a symptomatic anticoagulation therapy. In the TIPS group mean age was $36 \pm 13$ years (range: 20-60 years) and in the transplant group $27 \pm 9$ years (range: 14-34 years). 8 of 13 patients in the TIPS group underwent TIPS within one week after the diagnosis of BCS was confirmed, 3 patients underwent TIPS within 1 month, 1 patient within 2 months and in 1 patient time period until TIPS placement was 48 months.

The porto-systemic pressure gradient was lowered by a mean of $21 \pm 10 \mathrm{mmHg}$ (range: $6-40 \mathrm{mmHg}$ ) in the 13 patients initially treated with TIPS. After a median

Table 1 Baseline Characteristics of all Patients

\begin{tabular}{|c|c|c|c|c|c|}
\hline Patient & Underlying diagnosis & Clinical presentation & $\begin{array}{l}\text { Time of } \\
\text { presentation } \\
\text { (year) }\end{array}$ & $\begin{array}{l}\text { Time between primary } \\
\text { diagnosis and } \\
\text { intervention (months) }\end{array}$ & $\begin{array}{l}\text { Relevant } \\
\text { Comorbidities }\end{array}$ \\
\hline \multicolumn{6}{|c|}{ TIPS Group } \\
\hline 1 & Unknown & Abdominal pain & 2006 & 0 & None \\
\hline 2 & Polycythemia vera & Ascites & 2004 & 0 & Thyroidectomy, Schizophrenia \\
\hline 3 & $\begin{array}{l}\text { Factor V (Leiden) mutation, } \\
\text { protein C deficiency }\end{array}$ & $\begin{array}{l}\text { Abdominal pain and } \\
\text { ascites }\end{array}$ & 2005 & 0 & None \\
\hline 4 & Unknown & Abdominal pain & 1995 & 0 & Myocardial infarction \\
\hline 5 & Prothrombin mutation (20210) & Ascites & 2002 & 0 & $\begin{array}{l}\text { Myasthenia gravis } \\
\text { pseudoparalytica, Basedow } \\
\text { disease }\end{array}$ \\
\hline 6 & Polycythemia vera & $\begin{array}{l}\text { Abdominal pain and } \\
\text { ascites }\end{array}$ & 1998 & 1 & Arterial hypertension \\
\hline 7 & Polycythemia vera & $\begin{array}{l}\text { Abdominal pain and } \\
\text { ascites }\end{array}$ & 1996 & 2 & $\begin{array}{l}\text { Arterial hypertension, Atrial } \\
\text { fibrillation }\end{array}$ \\
\hline 8 & $\begin{array}{l}\text { Antiphospholipid antibody } \\
\text { syndrome, APC resistance }\end{array}$ & Abdominal pain & 1995 & 1 & Deep venous thrombosis \\
\hline 9 & Unknown & $\begin{array}{l}\text { Gastrointestinal } \\
\text { bleeding and ascites }\end{array}$ & 2001 & 1 & None \\
\hline 10 & Protein C and AT III deficiency & Abdominal pain & 2005 & 0 & None \\
\hline 11 & $\begin{array}{l}\text { APC resistance and AT II } \\
\text { deficiency }\end{array}$ & $\begin{array}{l}\text { Abdominal pain and } \\
\text { ascites }\end{array}$ & 2004 & 0 & Atrial septal defect \\
\hline 12 & Unknown & Abdominal pain & 1993 & 48 & None \\
\hline 13 & Oestrogen medication & $\begin{array}{l}\text { Abdominal pain and } \\
\text { ascites }\end{array}$ & 2007 & 0 & None \\
\hline \multicolumn{6}{|c|}{ OLT Group } \\
\hline 1 & Polycythemia vera & Abdominal pain & 1988 & 12 & None \\
\hline 2 & Protein $C$ and $S$ deficiency & Abdominal pain & 2001 & 48 & None \\
\hline 3 & Unknown & Ascites & 2003 & 36 & Sarcoidosis \\
\hline 4 & Unknown & $\begin{array}{l}\text { Abdominal pain and } \\
\text { ascites }\end{array}$ & 1992 & 24 & Osteoporosis \\
\hline \multicolumn{6}{|c|}{ Non-intervention Group } \\
\hline 1 & Myeloproliferative Disorder & Acute liver failure & 2005 & & None \\
\hline 2 & Factor V (Leiden) mutation & $\begin{array}{l}\text { Abdominal pain and } \\
\text { ascites }\end{array}$ & 2003 & & None \\
\hline 3 & Essential thrombocythemia & Abdominal pain & 2003 & & None \\
\hline
\end{tabular}


Table 2 Angiographic findings and interventions in the TIPS group

\begin{tabular}{|c|c|c|c|c|}
\hline Patient & Angiographic findings* & gradient reduction $* *$ & $\begin{array}{l}\text { Number of } \\
\text { additional Revisions }\end{array}$ & Follow up \\
\hline 1 & HV, PV, SMV occluded & $17 \rightarrow 8$ & 2 & 2 years \\
\hline 2 & HV occluded & $30 \rightarrow 7$ & 1 & 4 years \\
\hline 3 & HV occluded & $23 \rightarrow 10$ & 3 & 2 years \\
\hline 4 & HV occluded & $29 \rightarrow 12$ & 2 & 12 years \\
\hline 5 & HV occluded & $46 \rightarrow 6$ & 1 & 5 years \\
\hline 6 & HV, PV, IVC occluded & $35 \rightarrow 6$ & 8 & 7 years \\
\hline 7 & HV occluded & $32 \rightarrow 6$ & 4 & 11 years \\
\hline 8 & HV occluded & $25 \rightarrow 10$ & 1 & 3 years \\
\hline 9 & HV occluded & $20 \rightarrow 8$ & 2 & 6 years \\
\hline 10 & HV occluded & $32 \rightarrow 3$ & 0 & 3 years \\
\hline 11 & HV occluded & $31 \rightarrow 9$ & 3 & 3 years \\
\hline 12 & HV occluded & $10 \rightarrow 4$ & 6 & 10 years \\
\hline 13 & HV occluded & $38 \rightarrow 6$ & 0 & $1 / 2$ year \\
\hline
\end{tabular}

*HV: hepatic veins; PV: portal vein; SMV: superior mesenteric vein; IVC: inferior vena cava

${ }^{* *}$ Numbers indicate original portosystemic pressure gradient followed by post-TIPS gradient in $\mathrm{mmHg}$

follow-up of 4 years (range: 6 months to 12 years) 11 of these 13 patients (85\%) developed TIPS dysfunction requiring reintervention. In most cases TIPS dysfunction was due to thrombosis or pseudointimal hyperplasia and could be managed by dilation. On average, $2.5 \pm 2.2$ revisions per patient were necessary (range: $0-8$ ) (see table 2). 12 out of 13 patients survived within the follow up period (92\%). One patient died in the course of the underlying hematologic disease. After TIPS placement no patient developed clinical relevant hepatic encephalopathy. None of the patients in the TIPS group had to undergo OLT subsequently.

After a mean of $30 \pm 13$ months after diagnosis (range: $12-48$ months) patients in the transplant group underwent OLT. Each patient who underwent OLT as initial therapy, had to undergo re-OLT. The first patient had retransplantation within a few days because of portal vein thrombosis and graft failure. Today, 20 years after re-OLT she is still alive and has an excellent graft function. The second patient had to undergo 2 retransplantations. She had ischemic cholangiopathy in all explants and in the second explant ischemic cholangiopathy in relation with arterial thrombosis was found, histologically. The patient died due to septic complications 3 months after the third OLT. The third patient also had retransplantation within a few days because of vascular obliteration of the hepatic artery and a necrosis of the common bile duct. This patient is still alive without further complications. The fourth patient had to undergo retransplantation 9 months after initial OLT because of ischemic graft failure. She is still alive 15 years after OLT without limitations. Although no recurrence of BCS in the transplants has been detected, each patient in the transplant group suffered from various thrombotic complications. Within the observation period 3 out of 4 patients survived (75\%).

The overall probability of survival on an intention to treat basis for the whole cohort of 20 patients with BCS was $72.6 \%$ after a median follow-up of 5 years (range: 0 to 20 years), (see figure 1 ).

\section{Discussion}

In this study, we assessed the clinical course and long term outcome of patients with BCS referred to our university hospital analysing the data of all patients admitted with a primary diagnosis of BCS between 1988 and 2008.

Sequential use of increasingly invasive procedures based upon the clinical response has been recommended for the treatment of BCS $[8,25,27]$. In one study in 14 patients, treated with diuretics and anticoagulation alone, a mortality rate of $86 \%$ during a period of 6 months was reported [36], however acceptable long term survival rates with only medical therapy has been reported in other trials [37]. Surprisingly, in the recently published first prospective study [20] nearly $50 \%$ of the patients were managed conservatively, too. But there may be limitations of this study; on the one hand the study was not restricted to patients with severe disease and on the other hand the median follow-up was only 17 months. In our present trial only 2 patients have not had an invasive therapeutic procedure and are still without clinical symptoms under anticoagulation therapy. Both patients have incomplete hepatic venous outflow obstruction and presented with chronic or subacute BCS. In addition, in one of these two patients the follow-up period of half a year is relatively short. On the basis of this very limited experience, we may confirm the value of medical treatment alone in patients with 


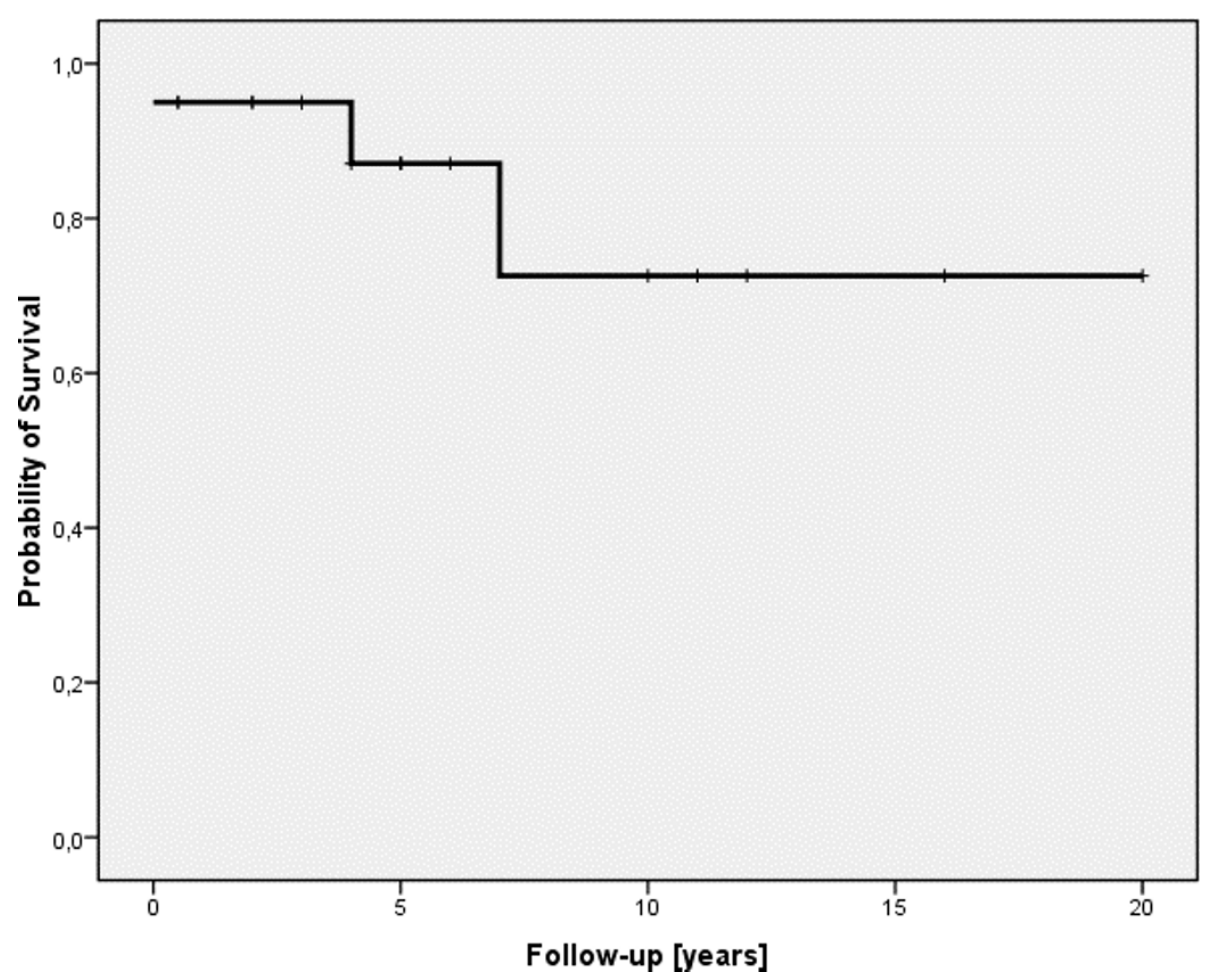

Figure 1 Probability of survival given for all BCS patients. On the $x$-axis the time of follow-up in years is given. On the $y$-axis the probability of survival is shown.

limited disease. In contrast, in the patients with severe disease or symptomatic cirrhosis, medical treatment was not effective and interventional treatment (TIPS) or transplantation had to be applied.

Different from the last Baveno consensus [26] treatment was only partly applied in a stepwise manner. On the basis of radiological imaging and the severity of clinical presentation a decision concerning adequate treatment was reached. In our collective 13 patients underwent TIPS as initial therapy. In the follow-up, one patient died in the course of the underlying hematologic disease so that an overall survival of $92 \%$ was achieved. In all patients transplantation could be avoided. Similar 5 year transplant free survival rates between 77 and $100 \%$ after TIPS were observed in other studies [11-13,22-25]. These results seem to justify primary TIPS treatment in patients with severe disease without awaiting failure of a previous treatment step. Both the high survival and the prevention of OLT in the patients initially treated with TIPS demonstrate an advantage over a stepwise strategy recommended by Baveno and applied in the study by Plessier et al. [8]. Although, the latter found high survival rates using therapeutic procedures by order of increasing invasiveness, the need for transplantation after TIPS was high (38\%) compared to our study. This may be due to the fact that TIPS is more efficient when inserted early. Therefore, our results suggest that TIPS should no longer be considered as a bridge to OLT but as a definitive treatment option in BCS, especially when prompt intervention and a high grade of interventional experience is available. With regard to the current situation of liver donor shortage these results are important.

Although, our protocol involved resumption of anticoagulation immediately after TIPS placement, $85 \%$ of our patients had at least one reintervention within a mean follow-up of 6 years. In all these patients TIPS revision was technically successful and effective. However, TIPS dysfunction seems to be a common problem $[38,39]$. Since, covered stents have a considerable advantage over bare stents with a lower dysfunction rate for the treatment of BCS patients [40], covered stents should be preferred.

Four patients underwent OLT as initial therapy. Two were transplanted before TIPS had been introduced as a treatment option of BCS and two had cirrhosis with signs of chronic liver failure. Survival following OLT depends upon the underlying cause of BCS and the patients condition at the time of transplantation [41]. A large series with 510 patients [42] found a 3 year patient survival of $85 \%$ after introduction of the Model for EndStage Liver Disease (MELD) score versus a 3 year 
patient survival of $73 \%$ in the pre-MELD era. In two other studies $[41,43] 10$ year survival rates were reported between 69 and $68 \%$, respectively. It has been suggested, that the outcome of OLT in BCS patients does not differ from that of other etiologies of liver failure when adequate longterm anticoagulation is administered [44]. Even in patients with myeloproliferative diseases survival rates are similar to those in patients with other underlying etiologies [41]. Although, the number of patients transplanted in the present trial does not allow any conclusions on survival, the overall survival rate of $75 \%$ during a mean follow-up period of 11 years is comparable to the reported results.

Each patient who underwent OLT as initial therapy, had to undergo re-OLT, which is one of the most important results of our study. All patients had graft failure due to thrombotic or vascular complications. These complications have been described in other series and severe thrombotic complications occurred despite routine early posttransplantation anticoagulation [8,41]. In accordance to other reports, these findings support the concept that aggressive anticoagulation as early as possible may reduce the risk of thrombembolic complications as well as the late recurrence of BCS after OLT $[41,43]$.

However, it seems likely, that in some cases thrombembolic complications will not be preventable, despite of aggressive anticoagulation as observed in one patient in our series.

\section{Conclusion}

In conclusion, therapy for BCS usually requires TIPS or OLT. The treatment modality is dependent on duration of illness, extent of thrombosis and degree of liver dysfunction. TIPS is successful as initial therapy as it promotes clinical improvement in the long run even though shunt revisions are generally needed. In the present study the necessity of subsequent OLT was remarkably low and thus TIPS could be regarded as definitive treatment option in BCS. OLT in BCS is associated with an increased risk of thrombembolic complications and early graft failure in spite of consequent anticoagulation therapy.

\footnotetext{
Author details

${ }^{1}$ Department of Gastroenterology, University Hospital Heidelberg, Im Neuenheimer Feld 410, 69120 Heidelberg, Germany. ${ }^{2}$ Department of Diagnostic Radiology, University Hospital Heidelberg, Im Neuenheimer Feld 110, 69120 Heidelberg, Germany. ${ }^{3}$ Department of Surgery, University Hospital Heidelberg, Im Neuenheimer Feld 110, 69120 Heidelberg, Germany.
}

\section{Authors' contributions}

AZ contributed substantially to the design of the study, performed data collection, data analysis and wrote the paper. DG contributed to the data collection and analysis. KHW contributed to the data collection and analysis. GR performed the radiological interventions, contributed to the data collection and analysis. JS contributed to the data collection and analysis concerning the transplant patients. WS contributed substantially to the design of the study and to the interpretation of data. PS developed the original idea of the study, was involved in data analysis and reviewed the manuscript finally. All authors read and approved the final manuscript.

\section{Competing interests}

The authors declare that they have no competing interests.

Received: 7 July 2009

Accepted: 1 March 2010 Published: 1 March 2010

\section{References}

1. Menon KV, Shah V, Kamath PS: The Budd-Chiari syndrome. N Engl J Med 2004, 350(6):578-585.

2. Valla DC: Hepatic vein thrombosis (Budd-Chiari syndrome). Semin Liver Dis 2002, 22(1):5-14

3. Denninger MH, Beldjord K, Durand F, Denie C, Valla D, Guillin MC: BuddChiari syndrome and factor V Leiden mutation. Lancet 1995, 345(8948):525-526

4. Hoffman R, Nimer A, Lanir N, Brenner B, Baruch Y: Budd-Chiari syndrome associated with factor $\mathrm{V}$ leiden mutation: a report of 6 patients. Liver Transp/ Surg 1999, 5(2):96-100.

5. Deltenre P, Denninger MH, Hillaire S, Guillin MC, Casadevall N, Briere J, Erlinger S, Valla DC: Factor V Leiden related Budd-Chiari syndrome. Gut 2001, 48(2):264-268

6. Slakey DP, Klein AS, Venbrux AC, Cameron JL: Budd-Chiari syndrome: current management options. Ann Surg 2001, 233(4):522-527.

7. Raju GS, Felver M, Olin JW, Satti SD: Thrombolysis for acute Budd-Chiari syndrome: case report and literature review. Am J Gastroenterol 1996, 91(6):1262-1263.

8. Plessier A, Sibert A, Consigny Y, Hakime A, Zappa M, Denninger MH, Condat B, Farges $\mathrm{O}$, Chagneau $\mathrm{C}$, de Ledinghen $\mathrm{V}$, et al: Aiming at minimal invasiveness as a therapeutic strategy for Budd-Chiari syndrome. Hepatology 2006, 44(5):1308-1316.

9. Fisher NC, McCafferty I, Dolapci M, Wali M, Buckels JA, Olliff SP, Elias E: Managing Budd-Chiari syndrome: a retrospective review of percutaneous hepatic vein angioplasty and surgical shunting. Gut 1999 44(4):568-574.

10. Venbrux AC, Mitchell SE, Savander SJ, Lund GB, Trerotola SO, Newman JS, Klein AS, Mitchell MC, Rosch J, Uchida BT, et al: Long-term results with the use of metallic stents in the inferior vena cava for treatment of BuddChiari syndrome. J Vasc Interv Radiol 1994, 5(3):411-416.

11. Ganger DR, Klapman JB, McDonald V, Matalon TA, Kaur S, Rosenblate H, Kane R, Saker M, Jensen DM: Transjugular intrahepatic portosystemic shunt (TIPS) for Budd-Chiari syndrome or portal vein thrombosis: review of indications and problems. Am J Gastroenterol 1999, 94(3):603-608.

12. Molmenti EP, Segev DL, Arepally A, Hong J, Thuluvath PJ, Rai R, Klein AS: The utility of TIPS in the management of Budd-Chiari syndrome. Ann Surg 2005, 241(6):978-981, discussion 982-973.

13. Eapen CE, Velissaris D, Heydtmann M, Gunson B, Olliff S, Elias E: Favourable medium term outcome following hepatic vein recanalisation and/or transjugular intrahepatic portosystemic shunt for Budd Chiari syndrome. Gut 2006, 55(6):878-884.

14. Blum U, Rossle $M$, Haag $\mathrm{K}$, Ochs $\mathrm{A}$, Blum HE, Hauenstein $\mathrm{KH}$, Astinet $\mathrm{F}$, Langer M: Budd-Chiari syndrome: technical, hemodynamic, and clinical results of treatment with transjugular intrahepatic portosystemic shunt. Radiology 1995, 197(3):805-811.

15. Orloff MJ, Daily PO, Orloff SL, Girard B, Orloff MS: A 27-year experience with surgical treatment of Budd-Chiari syndrome. Ann Surg 2000, 232(3):340-352.

16. Hemming AW, Langer B, Greig P, Taylor BR, Adams R, Heathcote EJ: Treatment of Budd-Chiari syndrome with portosystemic shunt or liver transplantation. Am J Surg 1996, 171(1):176-180, discussion 180-171..

17. Murad SD, Valla DC, de Groen PC, Zeitoun G, Hopmans JA, Haagsma EB, van Hoek B, Hansen BE, Rosendaal FR, Janssen HL: Determinants of survival and the effect of portosystemic shunting in patients with BuddChiari syndrome. Hepatology 2004, 39(2):500-508.

18. Srinivasan P, Rela M, Prachalias A, Muiesan P, Portmann B, Mufti GJ, Pagliuca A, O'Grady J, Heaton N: Liver transplantation for Budd-Chiari syndrome. Transplantation 2002, 73(6):973-977. 
19. Yamada T, Tanaka K, Ogura Y, Ko S, Nakajima Y, Takada Y, Uemoto S: Surgical techniques and long-term outcomes of living donor liver transplantation for Budd-Chiari syndrome. Am J Transplant 2006, 6(10):2463-2469

20. Darwish Murad S, Plessier A, Hernandez-Guerra M, Fabris F, Eapen CE, Bahr MJ, Trebicka J, Morard I, Lasser L, Heller J, et al: Etiology, management, and outcome of the Budd-Chiari syndrome. Ann Intern Med 2009, 151(3):167-175.

21. Langlet $P$, Escolano S, Valla D, Coste-Zeitoun D, Denie C, Mallet A, Levy VG, Franco D, Vinel JP, Belghiti J, et al: Clinicopathological forms and prognostic index in Budd-Chiari syndrome. J Hepatol 2003, 39(4):496-501.

22. Mancuso A, Fung K, Mela M, Tibballs J, Watkinson A, Burroughs AK, Patch D: TIPS for acute and chronic Budd-Chiari syndrome: a singlecentre experience. J Hepatol 2003, 38(6):751-754.

23. Perello A, Garcia-Pagan JC, Gilabert R, Suarez Y, Moitinho E, Cervantes F, Reverter JC, Escorsell A, Bosch J, Rodes J: TIPS is a useful long-term derivative therapy for patients with Budd-Chiari syndrome uncontrolled by medical therapy. Hepatology 2002, 35(1):132-139.

24. Rossle M, Olschewski M, Siegerstetter V, Berger E, Kurz K, Grandt D: The Budd-Chiari syndrome: outcome after treatment with the transjugular intrahepatic portosystemic shunt. Surgery 2004, 135(4):394-403.

25. Garcia-Pagan JC, Heydtmann M, Raffa S, Plessier A, Murad S, Fabris F, Vizzini G, Abraldes JG, Olliff S, Nicolini A, et al: TIPS for Budd-Chiari syndrome: long-term results and prognostics factors in 124 patients. Gastroenterology 2008, 135(3):808-815.

26. de Franchis R: Evolving consensus in portal hypertension. Report of the Baveno IV consensus workshop on methodology of diagnosis and therapy in portal hypertension. J Hepatol 2005, 43(1):167-176.

27. Klein AS: Management of Budd-Chiari syndrome. Liver Transp/ 2006, 12(11 Suppl 2):S23-28.

28. Janssen HL, Garcia-Pagan JC, Elias E, Mentha G, Hadengue A, Valla DC: Budd-Chiari syndrome: a review by an expert panel. J Hepatol 2003, 38(3):364-371.

29. Hadengue A, Poliquin M, Vilgrain V, Belghiti J, Degott C, Erlinger S, Benhamou JP: The changing scene of hepatic vein thrombosis: recognition of asymptomatic cases. Gastroenterology 1994, 106(4):1042-1047.

30. Richter GM, Palmaz JC, Noldge G, Rossle M, Siegerstetter $V$, Franke M, Wenz W: [The transjugular intrahepatic portosystemic stent-shunt. A new nonsurgical percutaneous method]. Radiologe 1989, 29(8):406-411.

31. Richter GM, Noeldge G, Palmaz JC, Roessle M: The transjugular intrahepatic portosystemic stent-shunt (TIPSS): results of a pilot study. Cardiovasc Intervent Radiol 1990, 13(3):200-207.

32. Richter GM, Noeldge G, Palmaz JC, Roessle M, Slegerstetter $V$, Franke M, Gerok W, Wenz W, Farthman E: Transjugular intrahepatic portacaval stent shunt: preliminary clinical results. Radiology 1990, 174(3 Pt 2):1027-1030.

33. Belghiti J, Panis Y, Sauvanet A, Gayet B, Fekete F: A new technique of side to side caval anastomosis during orthotopic hepatic transplantation without inferior vena caval occlusion. Surg Gynecol Obstet 1992, 175(3):270-272.

34. Calne RY, Williams R: Liver transplantation in man. I. Observations on technique and organization in five cases. Br Med J 1968, 4(5630):535-540.

35. Tzakis A, Todo S, Starzl TE: Orthotopic liver transplantation with preservation of the inferior vena cava. Ann Surg 1989, 210(5):649-652.

36. McCarthy PM, van Heerden JA, Adson MA, Schafer LW, Wiesner RH: The Budd-Chiari syndrome. Medical and surgical management of 30 patients. Arch Surg 1985, 120(6):657-662.

37. Zeitoun G, Escolano S, Hadengue A, Azar N, El Younsi M, Mallet A, Boudet MJ, Hay JM, Erlinger S, Benhamou JP, et al: Outcome of BuddChiari syndrome: a multivariate analysis of factors related to survival including surgical portosystemic shunting. Hepatology 1999, 30(1):84-89.

38. Ryu RK, Durham JD, Krysl J, Shrestha R, Everson GT, Stephens J, Kam I, Wachs M, Kumpe DA: Role of TIPS as a bridge to hepatic transplantation in Budd-Chiari syndrome. J Vasc Interv Radiol 1999, 10(6):799-805.

39. Bachet JB, Condat B, Hagege H, Plessier A, Consigny Y, Belghiti J, Valla D: Long-term portosystemic shunt patency as a determinant of outcome in Budd-Chiari syndrome. J Hepatol 2007, 46(1):60-68.

40. Hernandez-Guerra M, Turnes J, Rubinstein P, Olliff S, Elias E, Bosch J, GarciaPagan JC: PTFE-covered stents improve TIPS patency in Budd-Chiari syndrome. Hepatology 2004, 40(5):1197-1202.
41. Mentha G, Giostra E, Majno PE, Bechstein WO, Neuhaus P, O'Grady J, Praseedom RK, Burroughs AK, Le Treut YP, Kirkegaard P, et al: Liver transplantation for Budd-Chiari syndrome: A European study on 248 patients from 51 centres. J Hepatol 2006, 44(3):520-528.

42. Segev DL, Nguyen GC, Locke JE, Simpkins CE, Montgomery RA, Maley WR, Thuluvath PJ: Twenty years of liver transplantation for Budd-Chiari syndrome: a national registry analysis. Liver Transp/ 2007, 13(9):1285-1294.

43. Ringe B, Lang H, Oldhafer KJ, Gebel M, Flemming P, Georgii A, Borst HG, Pichlmayr R: Which is the best surgery for Budd-Chiari syndrome: venous decompression or liver transplantation? A single-center experience with 50 patients. Hepatology 1995, 21(5):1337-1344.

44. Knoop M, Lemmens HP, Langrehr JM, Bechstein WO, Blumhardt G, Schattenfroh N, Keck H, Neuhaus P: Liver transplantation for Budd-Chiari syndrome. Transplant Proc 1994, 26(6):3577-3578.

\section{Pre-publication history}

The pre-publication history for this paper can be accessed here:http://www. biomedcentral.com/1471-230X/10/25/prepub

doi:10.1186/1471-230X-10-25

Cite this article as: Zahn et al:: Budd-Chiari Syndrome: Long term success via hepatic decompression using transjugular intrahepatic porto-systemic shunt. BMC Gastroenterology 2010 10:25.

\section{Submit your next manuscript to BioMed Central and take full advantage of:}

- Convenient online submission

- Thorough peer review

- No space constraints or color figure charges

- Immediate publication on acceptance

- Inclusion in PubMed, CAS, Scopus and Google Scholar

- Research which is freely available for redistribution

Submit your manuscript at www.biomedcentral.com/submit
C Biomed Central 